\title{
MINIREVIEN (TIGG-07/02/90-MR-1)
}

\section{De-N-Glyoosylation of Glycoproteins in Animal Cells: Evidence for Occurrence and Significance}

\author{
Sadako INOUE \\ School of Pharmaceutical Sciences, Showa University, \\ 1-5-8 Hatanodai, Shinagawa-ku, Tokyo 142, Japan
}

In eukaryotic cells, the biosynthetic mechanism of protein N-glycosylation has been well established (1-3). However, the necessity for removing specific $\mathrm{N}-\mathrm{glycan}$ chain(s), if any, from certain glycoproteins, as possibly a prerequisite for intracellular transport and other unknown requirements, has yet to be demonstrated in any system.

During our structural and functional studies on glycoproteins found by the authors and considered essential to the embryogenesis of fish, the de-Nglycosylation of two types of glycoproteins differing completely in localization and function was found to definitely occur. The functional roles of glycan chains of glycoproteins are generally unclear even for biologically significant molecules such as those in fish eggs. Although the present findings are limited, the de-N-glycosylation of glycoproteins may be more widespread than presently considered and important for understanding the functional roles of $\mathrm{N}$-glycan chains, at least in some glycoproteins.

1. Intracellular accumulation of $\mathbf{N}-$ linked glyooprotein-derived free sialooligosaccharides in fish eggs.

That glycoproteins undergo de-Nglycosylation was first evident from a recent discovery of free sialooligosaccharides ( $M W$ 2000) in mature unfertilized eggs of the fresh water trout, plecoglossus altivelis (4). All the free sialooligosaccharides were composed of galactose, mannose, N-acetylglucosamine, and $\mathrm{N}$-acetylneuraminic acid. Structural analysis indicated them to be typical complex-type of bi-, tri-, and tetraantennary chains. The most important feature noted was that each oligosaccharide chain retains the di-N-acetylchitobiose structure GlcNACB1-4GlCNAC at the reducing terminus, indicating them to have originally been protein-linked components which became detached during oogenesis by the action of a putative peptide $\mathrm{N}^{4}-(\mathrm{N}-$ acetyl-B-glucosaminyll) asparagine amidase or peptide: N-glycosidase (PNGase) on a progenitor glycoprotein (see Scheme 1).

To our knowledge, there is no report on PNGase from an animal source, though PNGase activity has been detected in the extracts of various plant seeds and bacteria (5-11). The occurrence of endo- $\mathrm{B}-\mathrm{N}$-acetylglucosaminidase in animals has been reported (12). However, the products formed by this enzyme do not retain the di-Nacetylchitobiose structure. More recently, the intracellular accumulation of a novel class of disialobiantennary free oligosaccharides was observed in the unfertilized mature eggs of Tribolodon hakonensis, a dace (13), thus indicating the accumulation of free oligosaccharides to possibly be a general phenomenon in fish eggs. In normal animal tissues or cells, no accumulation of glycoprotein-derived free oligosaccharides was detected, 
TIGG Vol. 2 No.6 (1990)

$$
\text { ミニレビュー (TIGG-07/02/90-MR-1) }
$$

動物細胞におけるアスパラキン結合型桾鎖の遊離・De-N-Glycosylation 現象の発見とその意義

井上貞子

生物細胞で、榶タンパク質のアスパラギン 結合型糖鎖が形成する機構は既に解明されて いる(1-3)。しかし、動物細胞において、機能 上の目的から、アスパラギン結合型糖鎖が、 タンパク質との結合部位からそっくり切断さ れる(de-N-glycosylation) という現象は、 これまでに報告されていないようである。筆 者らは、最近、魚卵を材料とする榶タンパク 質の構造と機能の研究の過程で、局在性と機 能を異にする二種の榶タンパク質から、アス パラギン結合型糖鎖が遊離する現象を見いだ した。

魚卵榶タンパク質についてもそうであるが、 榶タンパク質が影著な機能をもっている場合 でも、糖鎖が何の為に結合しているのか、そ の機能は何かがはっきりしている例は少ない。 榶タンパク質を研究する者にとって最大のジ レンマであるこの問題を解明する上で、桾夕 ンパク質のde-N-glycosylation現象の発見は。 発想法の転換をもたらすものである。本稿で は、筆者らが見いだした事実を紹介し、含蓄 される問題点を提起したい。

\section{1 、魚卵における避離アスパラキン桔合型诺}

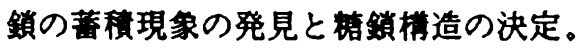

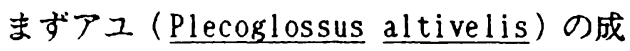
熟末受精卵細胞筫に、二千前後の分子量をも つ三種の榶鎖が遊離状態で存在することが見 いだされた(4)。これらは、ガラクトース、マ ンノース、Nーアセチルグルコサミン、およ びNーアセチルノイラミン酸から成ることか ら、糖タンパク質由来であることが推定され たが、構造解析の結果、ジー、トリーおよび テトラアンテナ型の典型的なアスパラギン結 合型榶鎖であることが明らかにされた。最も 注目すべき点は、これらの榶鎖がいずれも買 元末端にジーNーアセチルキトビオース構造 -GlcNac $\beta 1 \rightarrow 4 G 1 c N A C$ を保持していることで ある。すなわち、これらの遊離榶鎖はある榶 タンパク質から、酵素ペプチドー $\mathrm{N}^{4}-(\mathrm{N}-$ アセチルー $\beta$-グルコサミニル アアスパラギ ンアミダーゼ（PNGase）の作用を受けて切断 されたものである。糖タンパク質から、アス パラギン結合型糖鎖を付け根から切り離す離 す醭（PNGase）は、植物の種子や細菌に存 在することが知られているが、動物細胞に存 在する例は報告されていない(5-11)。一方、 動物細胞に存在するエンドー $-\mathrm{N}$-アセチ ルグルコサミニダーゼによる切断では、摆元 末端のNーア七チルキトビオース構造が保持 
possibly meaning that such glycan chains are immediately transported to lysosomes where they undergo further cleavage by glycohydrolases to constituent monosaccharides (12). The accumulation of oligosaccharides in tissues causes metabolic diseases.

In the following identification will first be made of progenitor glycoproteins for free oligosaccharides and the enzyme responsible for de-N-glycosylation. The mechanism (when and where) and significance of de-N-glycosylation in the oocytes will then be discussed and finally, whether de-Nglycosylation is universal mechanism for animals will be considered.

\section{Identification of progenitor glyco- proteins for free oligosaccharides in fish eggs.}

At the time the accumulation of free oligosaccharides was noted in fish eggs, vitellogenin was considered the source. This compound is a lipophosphoglycoprotein (MW 250-600K, reported for fish egg) synthesized in the liver of nonmammalian vertebrates, and taken from the bloodstream by growing oocytes which then process it into yolk proteins, lipovitellin (MW 20-200K) and phosvitin (MW 2-30K). These yolk proteins are the major proteinaceous components of eggs (80-90\% total protein in amphibian and fish eggs) (1416). Vitellogenin has a carbohydrate component, and the glycosylation of vitellogenin in the liver of Xenopus has been reported (17). No report, however, clearly states whether this carbohydrate is attached to lipovitellin (lipoprotein) or phosvitin (phosphoprotein), or both. Major phosvitin molecules from salmonid fish were previously shown to be linked hybridtype N-glycan chains (18). Hen egg phosvitin is a glycophosphoprotein although the carbohydrate structure given for it is hardly acceptable in the light of present knowledge $(19,20)$.

Glycophosphopeptides were shown present among the molecular species of the phosvitins of Plecoglossus and Tribolodon eggs and their carbohydrate structures were determined. In each fish species, the structures of oligosaccharide chains linked to the phosphopeptides are identical to those of free oligosaccharides accumulated in the eggs of respective species (21). Free oligosaccharides having structures identical to those of phosvitins were also found in Oryzias latipes eggs (22). These results support our first supposition that free oligosaccharides accumulated in fish eggs derived from vitellogenin during processing (vitellogenesis). What appears most probable is that the glycan chains of vitellogenin molecules are recognized by the receptor on the egg surface and participate in binding. Vitellogenin incorporation is a typical receptor-mediated endocytosis $(23,24)$ and to recycle the receptor incorporated into the cell dissociation of the ligand (vitellogenin) is prerequisite. The de-Nglycosylation of carbohydrate chain by PNGase would appear necessary for dissociation. One other reasoning is that de-N-glycosylation is necessary for proteolysis of vitellogenin to occur. Alternatively, glycan chains must be attached to limit the site of proteolysis and subsquent de-N-glycosylation occurs following the proteolysis for unknown reason. The identification of the enzyme involved in de-N-glycosylation and examination of the specificity and compartmentation of the enzyme activity should provide some clarification of these matters.

3. Release of glycan chains from Lhyosophorin during embryogenesis. 
されることがあり得ない(12)。

アユ卵に見いだされた遊離アスパラギン結 合型耞鎖榶タンパク質榶鎖の蓄積現象は、そ の後ウグイ（Tribolodon hakonensis）成熟未 受精卵でも見いだされ糖鎖構造が解析された (13)。ウグイ卵の場合にも、遊離榶鎖の遺元 末端にNーアセチルキトビオース構造を保持 するものが存在することから、アユ卵の場合 と同じく、PNGaseの作用による榶タンパク質 の糖鎖の切断が行われていることが推定され た。このように、糖タンパク質由来游離糖制 の蓄積現象は、魚卵に一般的な現象のようで あるが、これ迄他の動物細胞に見いだされた 例がないのは、偌鎖がたとえ遊離したとして も直ちにリソソームに送り込まれ、単糖レベ ルまで分解されてしまうからであろう。

魚卵におけるこれら遊離糖タンパク質糖鎖 の蓄積現象について、まず第一に解明されな ければならない問題点は、これらの榶鎖が由 来する榶夕ンパク質と、関与する醉素

(PNGase?）の同定であ)う。次の段階は、卵 細胞における榶鎖遊離機構（いつ、どこで起 こるか）とその生物学的意義の解明である。 更に、最終的には、このような楉タンパク質 のde-N-glycosylation機構が広く動物細胞に 存在することを証明し、その意義付けをする ことが、筆者らの目指すところである。

2.アユおよびウクイ未受精卵に翻されて

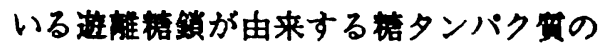
同定。

魚卵における遊離搪タンパク質榶鎖の蕃積
現象をはじめて見いだした段階において既に、 その量が多いことから、これらの榶鎖がビテ ロジェニンに由来するのではないかという推 测がなされた(4)。ビテロジェニンは肝䑏で合 成されるリン酸化リポ堶タンパク筫（魚卵の ものは分子量25-60万）で、卵細胞表面にある レセプターと結合して細胞内に取り込まれる と、直ちに特異的なプロテオリシスを受けて、 リボビテリン（分子量2-20万）とホスビチン （分子量数千一数万）に分解され卵黄粒に送 り迅まれる。このプロテオリシスによるプロ セッシングが行われないと、卵黄（yolk）は 形成されない。リポビテリンとホスビチンは 卵黄タンパク質の主たるものであり、同時に 卵全体のタンパク質の 80-90\%を占める(1416)。ビテロジェニンが埥を成分として持つこ とは古くから知られており、Xenopusの肝䑏で ビテロジェニンの糖鎖形成が起こることを示 した報告もあるが(17)、その榶鎖がリポビテ リン (リポタンパク質) の部分に結合してい るのかホスビチン (リンタンパク質) の部分 に結合しているのかについては確定的な報告 がない。筆者等は先にサケ科魚卵のホスビチ ンがハイブリッド型のアスパラギン䊅合型の 榶鎖を持つことを粗成分析の䊅果から示唆し た (18)。また旌卵のホスビチンが榶タンパク 質であることは報告されているが(19)、そこ で示された榶鎖構造は現在の知識からは受け 入れ難いものである(20)。

最近、籰者等はアユやウグイ卵のホスビチ ンに族鎖をもつ分子種があることを見いたしい、 それらの站鎖棈造の解析を行った。その結果、 
Hyosophorin is a family of glycoproteins found in fish eggs and identified as a component of cortical alveolus $(25-28)$. Its unique feature is that high molecular weight form ( $\mathrm{H}-$ hyosophorin, MW 100-200K) in unfertilized eggs undergoes specific proteolysis to produce the smallest repeating unit, L-hyosophorin (MW 7-9K) at the time of fertilization $(25,28)$. No degradation of glycan chains occurs in this depolymerization.

Seko et al. noted hyosophorinderived free glycan chains to be present in early embryos of the flounder, Paralichthys olivaceus (29). The free glycans have unusual pentaantennary structures typical of glycan chains of hyosophorin and retain the di-N-acetylchitobiose structure at their reducing termini. They also found hysophorin-derived free glycan chains in embryos of the Medaka, Oryzias latipes. These hyosophorin-derived glycan chains have never been found in unfertilized eggs or eggs following fertilization.

\section{Evidence for the de-N-glycosylation of a plant-seed glycoprotein.}

Ricin, a toxic lectin of Ricinus communis seeds, is a heterodimer whose subunits, A and B chains, are joined by a disulfide bond (30). The amino acid sequence of both subunits have been determined by Funatsu and coworkers (31). The most significant difference between the polypeptide structure deduced from the nucleotide sequence of cloned cDNA and the amino acid sequences determined directly for the $A$ and $B$ chains is that, at position 236 in the $A$ chain, the nucleotide sequence predicts asparagine (-Asn-Gly-Ser-) (32), whereas the amino acid sequence, an aspartate (-Asp-Gly-Ser-). Other partially sequenced cDNA clones also predict this Asn. Sequence analysis of cDNAs showed the precursor protein to contain four potential sites (Asn-XaaThr/Ser) for N-linked glycosylation at Asn-10 and -236 in the $A$ chain and at Asn-374 and -414 in the B chain. A 'heavy' or 'variant' form of the ricin A chain has been shown to actually contain two $\mathrm{N}$-linked oligosaccharide chains at Asn-10 and -236 (33). The structure of the $\mathrm{N}$-linked oligosaccharide chain at Asn-236 of the 'heavy' form of the ricin A chain has recently been reported (34). Considering these results together, a 'light' form of the ricin A chain is most likely formed from the 'heavy' form by site-specific de-N-glycosylation which converts the asparaginyl-glycosylamine bond at position 236 to aspartic acid. Asn$>$ Asp transformation by similar de-Nglycosylation may possibly be found on examining published amino acid sequences of proteins, Asp-Xaa-Thr/Ser sequences and the corresponding nucleotide sequences.

\section{The function of de-N-glycosylation}

Cotranslational N-glycosylation of secretory proteins appears essential particularly for the early steps of the secretory pathway to prevent the nonspecific aggregation of partially folded proteins following their synthesis for the aquisition of functional conformation(s) (35-39). But, once the proper functional conformation has been attained, the requirement for such glycan chains to be present in certain $\mathrm{N}$-linked glycoproteins may be less critical or even impede later events. Moreover, de-N-glycosylation, which may convert Asn residues to Asp (CHO-Asn to Asp) thus introducing negatively charged residues and alterating the macromolecular nature, may be one means 
アב卵とウグイ卵のいずれにおいても、ホス ビチンの桾鎖構造は、先に決定されたそれぞ れの魚卵に蓄積されている遊離瞊鎖の構造と 一致した(21)。また最近、メ夕゙カ未受精卵に もホスビチンの榶鎖と同一構造の榶鎖が遊離 状態で存在することを見いだした(22)。これ らの場合、各魚卵に特徽的な糖鎖構造が同定 の際の決め手となつた。この䊅果は、初めの 推測通り、魚卵に蓄積されている遊離榶鎖が ビテロジェニン由来であり、ビテロジェニン が卵にとりこまれ、分解のプロセッシングを 受けて卵黄が形成される過程で、糖鎖遊離が
起こると言う考えを支持するものである。こ こで最も単純で好都合な考えは、肝䑏で合成 され、血流によって運ばれたビテロジェニン が卵細胞表面のレセプターに認識される際に 糖鎖が関与するというものである。卵細胞に よるビテロジェニンの取り込みは、レセプタ 一の関与する典型的なエンドサイトーシスで あり(23.24)、ビテロジェニンと結合して卵細 胞内に取り込まれたレセプターを再生して元 の卵表面にもどす為には、リガンド（ビテロ ジェニン）を解離させる必要がある。この目 的の為にPNGaseが働いて榶鎖が切断されると

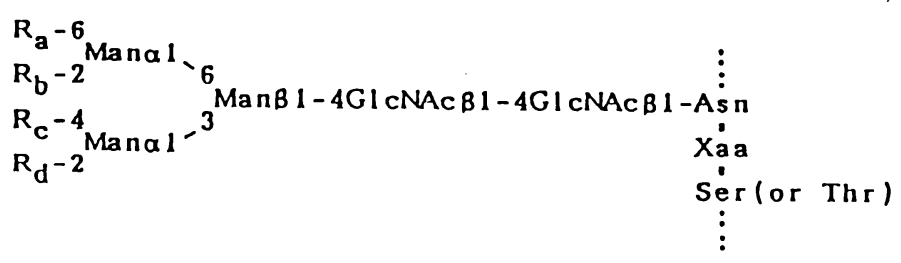

\section{GLYCOPROTEIN} peptlde:N-glycosldase (PNGase)

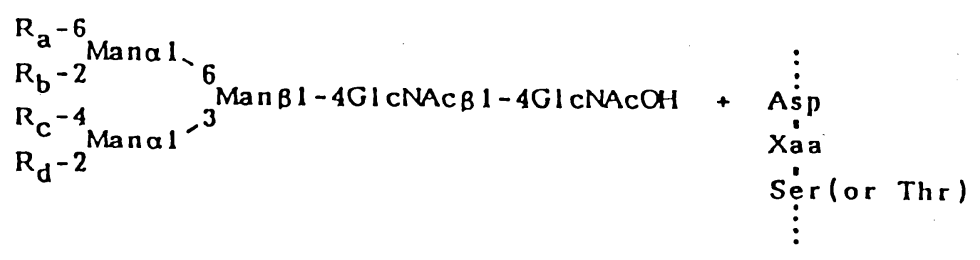

FREE GLYCAN

DEGLYCOPROTEIN

Scheme 1. A typical non-lysosamal degradation of asparagine-linked glycoproteins leading to the formation of bi-, tri-, and tetraantnnary "free" sialooligosaccharides found (4) in Plecoglossus altivelis eggs. $A-1: R_{a}=R_{C}=H, R_{b}=R_{d}=$ NeuAco2-3GalB1-4GlCNACB1-; A-2A: $R_{a}=H, R_{b}=R_{c}=R_{d}=$ NeuAco 2-3GalB1-4GlCNACB1-; A-2B: $R_{c}=H, R_{a}$ $=R_{b}=R_{d}=$ NeuAca2-3GalB1-4GlCNACB1-;A-3: $R_{a}=R_{b}=R_{c}=R_{d}=$ NeUACO2-3GalB1-4GlCNACB1-. 
for regulating the ligand-receptor interactions of certain secretory proteins at least in some cases. By this modification, the structural and functional properties of glycoproteins can be modulated. At the present, the authors are in no position to make any definite conclusions as to the functions of de-N-glycosylation or the free glycans liberated. Nevertheless, our finding of de-N-glycosylation as a possible basic biologic process may provide a new approach to the study of glycobiology. Too, it should be noted that, from a recent study on the metabolism of cell-associated proteoglycans, the glycosaminoglycan chains of cellsurface proteoglycans appear to be separated from protein cores in a nonlysosomal compartment prior to their transport to lysosomes for degradation (40-43).

\section{References}

1. Hanover, J.A., and Lennarz, W.J. (1981) Arch. Biochem. Biophys. $244,1-19$

2. Kornfeld, R. and Kornfeld, S. (1985) Ann. Rev. Biochem. 54, $631-664$

3. Lennarz, W.J. (1987) Biochemistry $\underline{23}, 7205-7210$

4. Ishii, K., Iwasaki, M., Inoue, S., Kenny, P.T.M., Komura, H., and Inoue, Y. (1989) J. Biol. Chem. 264, 1623-1630

5. Takahashi, N. (1977) Biochem. Biophys. Res. Commun. 76, 11941201

6. Plummer, T.H., Jr., Elder, J.H., Alexander, S., Phelan, A.W., and Tarentino, A.L. (1984) J. Biol. Chem. 259, 10700-10704

7. Tarentino, A.L., Gomez, C.M., and Plummer, T.H., Jr. (1985) Biochemistry 24, 4665-4671
8. Tarentino, A.L., and Plummer, T.H., Jr. (1987) Methods Enz. $138,770-778$

9. Plumer, T.H., Jr., Phelan, A.W., and Tarentino, A.L., (1987) Eur. J. Biochem. 163, 167-173

10. Hirani, S., Bernasconi, R.J., and Rasmussen, J.R. (1987) anal. Biochem. 162, 485-492

11. Maley, F., Trimble, R.B., Tarentino, A.L., Plumer Jr., T.H. (1989) Anal. Biochem. 180, 195204

12. Brassart, D., Baussant, T., Wieruszeski, J.-M., Strecker, G., Montreuil, J., and Michalski, J.C. (1987) Eur. J. Biochem. 169, $131-136$

13. Inoue, S., Iwasaki, M., Ishii, K., Kitajima, K., and Inoue, Y. (1989) J. Biol. Chem. 264, 1852018526

14. Wallace, R.A. (1985) in Developmental Biology (Brownder, L.W. ed.), vol. 1, pp 127-177, Plenum Press, New York

15. Ng, T.B., and Idler, D.R. (1983) in Fish Physiology, vol. IXA, pp 373-404, Academic Press, New York

16. Mommsen, T.P., and Walsh, P.J. (1988) in Fish Physiology, vol. XIA, pp 347-406, Academic Press, New York

17. Gottlieb, T.A., and Wallace, R.A. (1982) J. Biol. Chem. 257, 95-103

18. Tazawa, I., Inoue, Y., Iwasaki, M., Inoue, S., Okumoto, N., and Hayashi, F. (1988) Comp. Biochem. Physiol. 89B, 475-482

19. Shainkin, R., and Pearlmann, G.E. (1971) J. Biol. Chem. 246, 22782284

20. Shainkin, R., and Pearlmann, G.E. (1979) Arch. Biochem. Biophys. $145,693-700$

21. Iwasaki, M., and Inoue, S. (1989) Seikagaku 61, 1150 (in Japanese)

22. Kitajima, K., personal communica- 
いう考えは鬽力的である。一方、ビテロジェ ニンがプロテオリシスによるプロセッシング を受けるに先だって榶鎖が除去される必要が あると考えることもできる。また逆に、榶顉 の存在がプロテオリシスを受ける部位を限定 していることも考えられ、榶鎖の切断は特翼 的なプロテオリシスの後、別の理由で起こる と言う考えも否定できない。いずれにせよ、 榶鎖の切断に動く醉素を同定し、その湅胞内 局在部位（compartmentation）や特異性を調 ベる研究によって解明すべき問題である。

\section{3. 魚卵初期発生におけるL-hyosophorinから の榙顉の遊離。}

hyosophorinは筆者等が魚卵に見いだし、表 層胞局在を明らかにした一群の墦タンパク筫 である(25-28)。hyosophorinの最も著しい特 徵は、未受精卵に存在する分子量10-20万の高 分子型 (H-hyosophorin) が、受精または卵活 性化に伴って特異的なプロテオリシスを受け、
H-hyosophorinの最小反復単位である分子量7 -9千の低分子型 (L-hyosophorin) に低分子化 する現象である(25.28)。このとき、群鎖の切 断は全く起こっていない。ところが最近、倾 古等は、ヒラメ(Paralichthys olivaceus) 初 期胚にhyosophorin由来の榶鎮が遊離状態で存 在することを見いだした(29)。hyosophorinの 据鎖は他の榶タンパク質に見られない特徽的 なペンタアンテナ型構造を持つため、ここで 見いだされた遊離榶鎖がhyosophorin由来であ ることは疑いなかった。更に最近、瀨古等は、 メダカの初期胚にも、hyosophorin由来の詥镍 が遊離状態で存在することを見いだした。 hyosophorin由来の榶鎖は、未受精卵队受精直 後の卵には決して存在しない。肧発生のある 特定の時期に榶鎖の遊離が起こるのである。 これらの事実が、初期発生における hyosophorinの機能を解く鍵を㩧っているもの と思われ、研究が進められている。

\section{Some llke It hot}
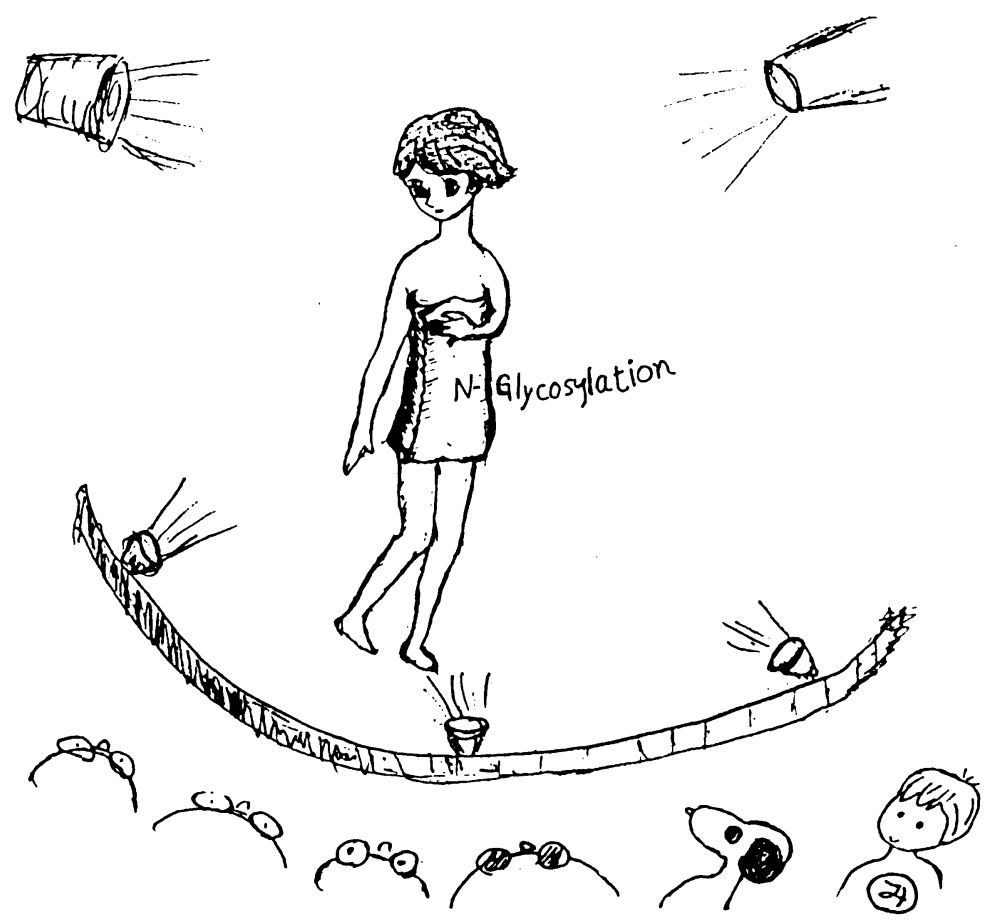
tion

23. Opresko, L., Wiley, H.S., and wallace, R.A. (1980) Cell 22, 4757

24. Busson-Mabillot, S. (1984) Biol. Cell 51, 53-66

25. Inoue, S., and Inoue, Y. (1986) J. Biol. Chem. 261, 5256-5261

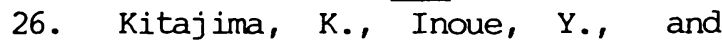
Inoue, S. (1986) J. Biol. Chem. $\underline{261}, 5262-5269$

27. Kitajima, K., Inoue, S., and Inoue, Y. (1989) Dev. Biol. 132, 544-553

28. Seko, A., Kitajima, K., Iwasaki, M., Inoue, $S_{\text {., }}$ and Inoue, Y. (1989) J. Biol. Chem. 264, 1592215929

29. Olsnes, S., and Phihl, A. in Molecular Action of Toxins and Viruses (1982) pp 51, (Cohen, P., and Van Heyningen, S., eds.) Elsevier Biomedical, Press Amsterdam

30. Yoshitake, S., Funatsu, G., and Funatsu, M. (1978) Agric. Biol. Chem. 42, 1267-1274

31. Funatsu, G., Kimura, M., and Funatsu, M. (1979) Agric. Biol. Chem. 43, 2221-2224

32. Lamb, F.I., Roberts, L.M., and Lord, J.M. (1985) Eur. J. Biochem. 148, 265-270

33. Quoted in ref. 32 as personal communication from Foxwell, B.

34. Kimura, Y., Kusuoku, H., Tada, M., Takagi, S., and Funatsu, G. (1989) Seikagaku 61, 1020 (in Japanese)

35. Freedman, R.B. (1989) Biochem. Soc. Trans. 17, 331-335

36. Slieker, L.J., Martensen, T.M., and Lane, M.D. (1986) J. Biol. Chem. 261, 15233-15241

37. Olson, T.S., and Lane, M.D. (1987) J. Biol. Chem. 262, 68166822

38. Olson, T.S., Bamberger, M.J., and
Lane, M.D. (1988) J. Biol. Chem. $\underline{263}, 7342-7351$

39. Schulke, N., and schmid, F.X. (1988) J. Biol. Chem. 263, 88328837

40. Lark, M.W., and Culp, L.A. (1983) Biochemistry 22, 2289-2296

41. Brauker, J.H., and Wang, J.L. (1987) J. Biol. Chem. 262, 1309313101

42. Dean, R.T., Jessup, W., and Roberts, C.R. (1984) Biochem. J. $\underline{217}, 27-40$

43. Piepkorn, M., Hovingh, P., and Linker, A. (1989) J. Biol. Chem. $\underline{264}, 8662-8669$ 
4. 魚卵以外の系においても落夕ンパク貫の de-N-glycosylation起こっていることを 示す事実。

リシンはヒマ(Ricinus communis)の種子 に存在するレクチンで、Aと Bのサブュニッ トからなる(30)。AとB鎖のアミノ酸配列は 船津等により決定された(31)。ここで、A鎖 の236番目のアミノ酸怯アミノ酸配列分析から はAspであるが、C D N AからはAsnと決めら れた (32)。リシンをコードしているいくつか の c D N Aクローンを得、それらの塩基配列 を決定した結果は、いずれもAsnであることを 示している。また、C D N Aの解析によると $\mathrm{A}$ 鎖のAsn-10と-236、B 鎖のAsn-374と-414が 糖鎖結合可能なサイト（Asn-Xaa-Thr/Ser）で ある。ところで最近、リシンA 鎖のheavy型 (バリアント) が分離され、れにはAsn-10に 加えてAsn-236にも榶鎖が結合していることが 報告された ${ }^{(33)}$ 。リシンA 鎖heavy型のAsn236に結合した糖鎖の構造は最近決定された (34)。

そこで考えられるのは、heavy型のAsn-236 に結合した廎鎖のde-N-glycosylationによっ て通常のlight型が形成したのではないかとい うことである。この考えに従えば、アミノ酸 配列分析からAspとされたA 鎖の236番目のア ミノ酸に対するヌクレオチドのコードがAsnと なっていることが、よく説明できる。既に報 告されているタンパク賁のアミノ酸配列の中 から、榶鎖結合の可能な配列に対応するAspXaa-Thr/Serなる配列を拾い上げ、それらの Aspに対するヌクレオチドコードを調べる作業
を行うことによって、このような例が更に見 つかる可能性があると思われる。

5. de-N-glycosylationの機能は何か? 分泌性タンパク質においてアスパラギン結 合型榶鎖は、特に分泌の初期過程でタンパク 質が非特異的な構造变化を起こすのを防止し、 機能に必要なコンホメーションをとるために 不可欠とされている(35-39)。しかし、一旦必 要なコンホメーションが固定されてしまえば、 アスパラギン結合型糖鎖の存在は不要かむし ろ有害である場合もあるのではないか。また、 de-N-glycosylationによって糖鎖と結合して いたAsnがAspに変換されれば、その部位に負 電荷が導入される。この変換によって分泌性 タンパク筫とレセプターとの相互作用など、 細胞内の特定の部位で糖タンパク質の榙造が 变化し、機能調節が行われるという機構も考 えられる。de-N-glycosylationとそれによっ て遊㳯される榶鎖の機能に関して碓かな結論 を下す為には、更に多くの知見が必要である。 de-N-glycosylationという現象の発見は、蓎 タンパク質榶鎖の機能に関して新しい着想を 産み、glycobiologyの分野に新しい研究課題 を提供するものであろう。

尚最近、プロテオグリカンの代謝の研究で、 細胞表面のプロテオグリカンのグリコサミノ グリカン鎖がコアタンパク質から切断される 反応が、リソソームに遇ばれて分解される前 にリソソームとは別の部位で行われるという 報告がある(40-43)。 